\title{
ASSOCIATION BETWEEN ENVIRONMENTAL FACTORS AND TUBERCULOSIS AMONG CHILDREN AGED O-14 YEARS IN KUPANG, EAST NUSA TENGGARA
}

\author{
Merina Regifana Loak, Imelda F.E. Manurung, Jacob M. Ratu \\ Pius Weraman, Anderias Umbu Roga \\ Masters Program in Public Health, Universitas Nusa Cendana, Kupang
}

\begin{abstract}
Background: The best-known health impacts are related to environmental (air) pollution, poor water quality, and inadequate sanitation. Tuberculosis (TB) occurs in poor socio-environmental conditions where mean infectivity cases are able to maintain a sufficiently high effective contact number. This study aimed to examine the association between environmental factors and TB among children aged o-14 years in Kupang, East Nusa Tenggara.

Subjects and Method: A case control study was carried out at 14 community health centers in Kupang, East Nusa Tenggara. A sample of 141 children aged 0-14 years old was selected for this study purposively. The dependent variable was TB. The independent variables were occupancy density and light exposure. Data on TB status were obtained from medical record. The other data were collected by questionnaire and observation. The data were analyzed by a multiple logistic regression.

Results: TB in children aged 0-14 years old increased with high occupancy density $(\mathrm{OR}=11.51 ; 95 \% \mathrm{CI}=1.91$ to $69.44 ; \mathrm{p}=0.008)$ and low light exposure $(\mathrm{OR}=2.99 ; 95 \%$ $\mathrm{CI}=1.18$ to $7.48 ; \mathrm{p}=0.022$ ).

Conclusion: TB in children aged $0-14$ years increases with high occupancy density and low light exposure.
\end{abstract}

Keywords: tuberculosis, environmental factors, children aged 0-14 years old

Correspondence:

Merina Regifana Loak. Masters Program in Public Health, Universitas Nusa Cendana. Jl. Adi Sucipto Penfui, Kupang, East Nusa Tenggara, Indonesia. Email: merinaregifanaloak@gmail.com.

The $6^{\text {th }}$ International Conference on Public Health

Best Western Premier Hotel, Solo, Indonesia, October 23-24, 2019 | 35 https://doi.org/10.26911/the6thicph.01.12 